\title{
Music, personhood, and eudaimonia: Implications for educative and ethical music education
}

\author{
DJ ELLIOTT' AND M SILVERMAN
}

\begin{abstract}
This paper proposes that educative and ethical music making and teaching, which is based on a praxial philosophy of music education (Elliott and Silverman, 2014), can be carried out in a variety of ways that create places and spaces, in schools and community settings, for a variety of human values or "goods" that include, but go beyond, making and listening to classical instrumental music, or any other kind of music, for "the music itself."

One premise of this philosophical discussion is that music does not have one value; music has numerous values, depending on the ways in which it is conceived, used, and taught by people who engage in specific musical styles. For example, when music education is ethically guided-when we teach people not only in and about music, but also through music - we achieve what Aristotle and many other philosophers consider the highest human value-eudaimonia - which is a multidimensional term we explain the body of this paper.

Following an examination of three community music settings that exemplify educative and ethical musical interactions, the paper provides a brief explanation of the nature of personhood that draws from embodied, enactive, empathetic, and ecological concepts put forth by several contemporary cognitive scientists and philosophers of mind nature. This sections leads to an examination to main constituents of eudaimonia: happiness and wellbeing as conceived by various scholars during the last 2500 years.

The discussion ends by integrated the above themes with a discussion of a praxial philosophy of music education and its implications for school and community music education.
\end{abstract}

Keywords. School music, community music, ethics, praxis, personhood, well-being

What does it take to educate the students we serve? Pedro Noguera (2009), a renowned New York University educational scholar, argues that, "If you cannot answer that question, you shouldn't be doing this work. But it's not a simple question. Because to answer the question, you have to know and understand the children [all students] you serve."

1 David Elliott is a Professor of Music and Music Education at the Steinhardt School of Culture, Education, and Human Development, New York University. davidelliott1@gmail.com

2 Marissa Silverman is Associate Professor and Coordinator of Undergraduate Music Education at John J. Cali School of Music, Montclair State University. silvermanm@mail.montclair.edu 
What does it mean to know and understand our students? And why should music educators, university music professors, private studio teachers, community music facilitators care about the meanings and implications of personhood and eudaimonia? Regardless of students' ages, or the fields of music we are preparing them for, "doing this work" effectively, educatively, and ethically means that our aims and teaching strategies should include enabling our students to achieve musical and personal abilities and dispositions that will increase the likelihood that they will experience deeper and broader eudaimonic values now and in the future.

In other words, music education of whatever kind-in the contexts of schools and/or community music settings of all kinds-is not only about improving people's technical musical skills, artistry, creativity, and verbal musical knowledge to whatever level they choose to achieve. It is also about being continuously mindful that one's school or university students, and/or the children, youth, and adults one is teaching in various kinds of community music settings, are as important as the musical abilities they are working to acquire. Music students and amateur musicians who become miserable, unhealthy, discouraged, anxious (and so on) during their music learning and music making experiences will not achieve their musical potential, and they will certainly not experience the joys and other values of music making. In some instances, they may grow to hate music altogether.

Educative and ethical music teaching and music making balances the care, growth, and positive transformation of students as persons with teaching strategies and conditions that foster artistry. Music education can humanize, but it can also dehumanize. It depends. It depends on whether music educators are educative, or not.

Again, we are not saying that musicianship and musicality-including musical-artisticcreative skills and understandings - are secondary. What we are suggesting is that when music teaching and learning are exclusively concerned with "the music," then it is less likely that students' experiences will not be as effective, intrinsically joyful, and artistically motivating as they could be. Thus, in addition to being informed about students' musical and educational needs and desires, music educators at all levels of instruction (elementary, secondary, tertiary) should be mindful of each student's multidimensional personhoodartistic, emotional, cognitive, social, cultural, and personal.

To take an extreme but useful example, while the great German conductor Herbert von Karajan was an astonishing artist-due to his profound talent and training - he made the deliberate decision to continue conducting and recording in Germany throughout the period of the Third Reich, thereby supporting Hitler's dictatorship and feeding his own appetite for musical recognition and promotion. He was "taught and trained" well, in the sense that he received superb instruction. But he was not given a fully educative and ethical musical education, which may have motivated and guided him to make the crucial moral decision to leave the Third Reich and continue his musical career in a democratic nation, which many other superb German musicians did.

This paper proposes that educative and ethical music making and teaching, which is based on a praxial philosophy of music education (Elliott and Silverman, 2014), can be carried out in a variety of ways that create places and spaces (in schools and community settings) for a variety of human values or "goods" that include, but go beyond, making and listening to classical instrumental music for "the music itself."

Indeed, music does not have one value; music has numerous values, depending on the ways in 
which it is conceived, used, and taught by people who engage in specific musical styles. For example, when music education is ethically guided-when we teach people not only in and about music, but also through music - we achieve what Aristotle and many other philosophers consider the highest human value-eudaimonia-which is a multidimensional term that means full human flourishing: a "good life" of significant, enjoyable, and meaningful work and leisure; personal and community health and well-being; virtue; and fellowship, selfworth, and happiness for the benefit of oneself and others. Any reader who may find these values academically "soft," extramusical, or irrelevant to music education and community music may want to consider this: What these values have in common is the fact that people seldom ask, "Why do you want . . . happiness, health and well-being, enjoyment, self-worth, fellowship, and similar values?" (Beck, 1974, p. 21). Thus, in our praxial philosophy of music and music education, both musical artistry and eudaimonia are among the ultimate aims of music making and music teaching and learning.

The following discussion proceeds in four sections. First, we discuss three contrasting, reallife examples of music and community music being "put to work" for social justice, positive identity formation, health and well-being, and the enhancement of personal and community happiness and transformation. Next, we provide a very brief introduction to the nature of personhood, which we explain in detail elsewhere (Elliott and Silverman, 2014). In the third section, we focus on the nature of happiness-a central constituent of full human flourishing - which is frequently misunderstood, despite the fact that happiness has a central place in everyone's life, that people frequently find great happiness in making and listening to music, and that happiness has been at the center of centuries of philosophical, psychological, sociological and, recently, neuroscientific research. We conclude with several implications for music teaching and learning.

\section{Community Music Narratives: Three Examples of Educative Music Engagement}

The city of Limerick, Ireland is situated along the banks of the River Shannon. Picturesque and culturally rich, it is the fourth most populated city in all of Ireland. As such, its population has become much more diverse in recent decades due to the advent of the EU and its erasure of traditional border restrictions. In 2001, Helen Phelan, professor and director of the masters program in Ritual Chant and Song, sought to meet the needs of newly migrant communities in Ireland. She has achieved many of her aims by establishing "Sanctuary," an open-access community music program that acts as a support group for new migrants in Limerick. The program, funded by the Higher Education Authority of Ireland, is an outreach project of the Irish World Academy of Music and Dance at the University of Limerick. Sanctuary works in partnership with Doras Luimní, the support group for refugees, asylum seekers, and new immigrants.

One of the first community-based initiatives of "Sanctuary" was the creation of a women's choir called Combcheol (the Gaelic word for "harmony") that brought together women from Ireland's traveller community and from immigrant communities in Ireland. The choir met once per week at the University of Limerick, and the women's travel expenses were paid by Sanctuary. Additionally, all children were welcome. Repertoire consisted of song exchanges, supported by a number of musical facilitators including Phelan and members of the Irish Chamber Orchestra, another dimension of the Irish World Academy of Music and Dance. 
Phelan became increasingly aware of the particular obstacles women encountered in Ireland as they en yde yavoured to gain access to higher education. One major obstacle was the absence of child care facilities, which affected many women, "particularly those in the asylum process, [who] were single parents, having come to Ireland alone or in advance of a spouse" (2012, p. 172). Elsewhere, Phelan (2008) writes:
The goals of the choir, from the outset, were explicit. These involved exposure to university life through participation in a cultural activity, embodied in the cultural exchange of repertoire from the travelling community and the cultures represented within the asylum seeking community, as well as the provision of a creative space for women to explore music-making. (p. 151)

Issues surrounding discrimination and integration emerged quickly within the group. In a film documentary of the project, one of the women from the traveller community reflected on her experiences of discrimination, shared by women from the traveller community and other migrant backgrounds:

\section{There's a lot of discrimination against travellers, and there's a lot of discrimination against the refugee people, like, which it's wrong, between the both sides, it's wrong (Combcheol documentary, quoted in Phelan, 2012, p. 173).}

Phelan continued her efforts to alleviate the women's feelings of alienation by inviting the women to bring, introduce, and teach the songs that pertained to their respective identities. The women and children sang Igbo, Yoruba and Romanian songs, as well as songs in Cant, the traditional language of the travellers. They also sang songs from "Sister Act" and Irish ballads. Phelan (2012) states: "Repertoire provided the currency of exchange, with culture bearers from diverse communities offering their expertise and knowledge to the group" ( $\mathrm{p}$. 173). Doing so proved to be highly effective for these women. Phelan (2008) noticed that the women began to open themselves up to the musically embodied identities: "Instead of singing songs which might be viewed as embodying their own identities, they choose instead to select repertoires which reflected their sense of the other community" (p. 151). Joe McGlynn, a founding member of Doras Luimni, observed how performing in this choir helped bridge the social, political, ethnic, and emotional hardships the women were facing, especially those who were experiencing isolation. In what follows we summarize and paraphrase McGlynn's observations, as originally documented in a documentary (Combcheol documentary, 2001, cited in Phelan, 2012, p. 173): Through choral singing, I think there will be a lot more musical healing and positive communal transformation that will help to ease immigrants' feelings of alienation in these minority groups in Limerick.

Moving now to a completely different context: In New York City, the Hip-Hop Project-a community music project that focuses on New York City youth and Hip-Hop composition and recording-is related to a broader initiative called Art Start. This program began when a group of New York artists decided to reach out to homeless and "at-risk" youth in the city by teaching them to use creative outlets to work through problematic issues. Art Start gives these youth the opportunity to belong to an artistic community and, thereby, to make their voices heard. Through this process, the young people have a chance to heal themselves and their own communities.

Unfortunately, according to Scott Rosenberg, the founder of Art Start, the program only reaches a limited number of youth. Indeed, tens of thousands of children live in New York City homeless shelters on any given night (Bernstein, 2001). Rosenberg points out that 
because these youth "have had to survive and not crumble," they have "developed so much strength, and as a result, they have a lot to offer."

Since its inception, Art Start has introduced 1700 children to more than 200 artists and educators through Arts in Shelters and Media Works, which are aimed at teens in "lastchance schools.” As Rosenberg states:

As exhilarating as it is to work with the kids and see them blossom, it's also very
draining and tough - to me, that's where the artists are heroic. No one in Art Start has
gotten a penny for what they do, and it's rare that we have money to reimburse anyone
for resources. (Connect America, 1997)

Still, the directors of Art Start are hopeful that they will eventually build a fully functioning center with music, art, and media studios, as well as performance and gallery spaces. In addition, they envision a student-run store where the proceeds will go towards Scholarship Enterprise Funds.

Chris "Kazi" Rolle founded the Hip-Hop Project. Born in Nassau, Bahamas, Rolle was abandoned by his mother as a young child. When he was 14 (after living in foster care and orphanages), Rolle decided to come to New York City to reconnect with his biological mother. Sadly, the reunion failed, and Rolle became homeless in Brooklyn. At 18, and after years living on the streets, Rolle found the courage to work toward putting his life back in order (Talcott, 2007). He enrolled in the Public School Repertory Company, a "last chance" performing arts high school, where he discovered his passion for music and theater. While there, Rolle joined Art Start. After experiencing the "healing power of the arts," Rolle (2007) created the Hip-Hop Project, a community music program that "connects underserved New York City teens to music industry professionals, who help them write, produce, and market their own compilation albums on youth issues."

Due to Rolle's musical skills and creativity, his praxial-ethical mindset, and his empathetic disposition, teens involved in the Hip-Hop Project began to create Hip-Hop pieces that expressed their deeply personal narratives. Rolle enabled and empowered the young people to rap about issues they felt uncomfortable discussing and to express their feelings creatively, in order to work through their pain. As Rolle stated in an interview with Kam Williams (2007):
For folks living in tough situations, like foster care, or the homeless, I'd say to them, "Try to surround yourself with people who care. There are people out there. Sometimes, it won't be blood relatives, but you've got to surround yourself with people who tell you that you can be somebody, and that, whatever you need, they will support you." And for folks who want to break into the music industry, I'd say, "Just be honest in your music. Write music that comes from your heart ... that represents you. Don't let the radio dictate to you who you should be. Use the internet as a way to find your fan base. Use places like MySpace and Facebook to promote your stuff right there online. That's the future of music." (p. 4)

Through their increasing musical-narrative abilities, the teens became more and more adept at expressing their pain, biases, negative assumptions about others, and so forth. In doing so, many navigated and gradually abandoned the misogynistic, racist, and violent attitudes that commercial rap and Hip-Hop often espouse toward musical-narrative expressions of serious personal and community issues they were dealing with on a daily basis in their own lives, such as abortion, violence, drugs, death, and absent fathers. 
Moving now to a third and totally different context, Gregory Barz (2006) writes:

Today in Uganda, only 10 percent of the population has access to medical facilities; there is only one doctor for every twenty thousand people... While infection rates have fallen in Uganda, down from 30 percent to 5 percent in the past ten years, two million orphans and one million persons living with AIDS represent a need for care that cannot be met by currently available medical resources. (p. 4)

Barz continues: "At the time of this writing, 38 million people are infected with the HIV virus worldwide. Over two-thirds, nearly 67 percent-or roughly 25.3 million children and adults-live in sub-Saharan Africa" (p. 9). What could music possibly do to help alleviate the suffering attached to this horrendous epidemic?

Barz explains that the power of song is used "to educate Ugandans about the disease, to inform non-governmental organizations about the power of music in the lives of those living with and dying of HIV/AIDS, and to make known to the world the contours of Uganda's tales of life, death, and disease" (Muller, 2008, p. 113).

Because cultural memory in Uganda is frequently maintained within music and musical responses, Barz engaged one community in creating, performing, and listening to their own songs about HIV/AIDS and the efforts of traditional healers and medical doctors in their midst. Gradually, the community became more hopeful as their songs moved from musical expressions of profound grief, stress, and despair to expressions of hope for a more positive life. As Barz (2008) says, music was able to "re-memory" the community-to "change the memory of AIDS among listeners and thus shift the attitude that accompanies disease toward one of positive living" (p. 165). It was the people's embodied musical-emotional engagements, expressions, and experiences of with and of music that empowered them to positively shift their community's identity and associations with AIDS and to reframe their autobiographical selves.

Having sketched several practical examples of ethical musicing and praxial music education for well-being, let us examine briefly the nature of personhood, and follow this with reflections on well-being and happiness. Doing so is intended to further support our argument that music making provides a vital and widely shared way for people of all ages to work toward and achieve major "goods" that eudaimonia includes.

\section{Personhood: A Very Brief Introduction}

Music is made by and for persons. All forms of music, education, and community music pivot on personal-social endeavours and encounters. Music making and listening involve personaland social-sonic (corporeal, visual, tactile, etc.) actions and events, interpersonal engagements, personal and collective emotions, and the relationships of all of these to the individual circumstances and needs of persons living with and for other persons. More precisely, learners of all ages are unique, social, cultural, emotional, corporeal, cognitive, intersubjective, empathetic, and gendered human agents. In other words, our intrapersonal and interpersonal experiences of music making, listening, feeling, knowing, teaching, learning-everything we can possibly do, desire, feel, think, etc.-trace back to the fundamental issue of what it means to be the kind of being that possesses, undergoes, enacts, and "performs" his or her personhood. 
If so, then any effort to develop a basis for understanding links between music, music education, community music and eudaimonia should attempt to develop basic perspectives on what it means to be a person living in his or her social-cultural world(s). As we proposed at the outset, educative musicians and teachers have an ethical responsibility and a practical need to understand the people (infants, children, adolescents, adults, and/or seniors) we serve.

So, how can we provide in this short article a basic sense of what personhood seems to involve? Let us suggest, in brief, that personhood includes, but is not limited to, conscious self-awareness, self-identity, spirituality, and our powers of attention, perception, cognition, emotion, memory, and volition that emerge from, express, and develop because all dimensions of our personhood are unified and engage continuously with our socially situated communities, norms, and values. In addition, and more fundamentally, all these attributes of personhood are anchored in and emerge from an underlying set of "personhood processes" that are unified, dynamic, and responsive to our individual environments. These processes include: the body-brain-mind (each is a process, not a "thing"; and each depends on all the others); our conscious and nonconscious processes that arise in virtue of our unified bodybrain-mind. As philosopher and cognitive scientist Mark Johnson (2007) explains, personhood includes a brain operating in and for "a living, purposive body, in continual engagement with complex environments that are not just physical, but social and cultural as well" (p. 175). Notably and emphatically, then, the brain is only one part of personhood. Personhood includes and combines "a functioning human brain, in a living human body, interacting with complex physical, social, and cultural environments, in an on-going flow of experiences" (Johnson, 2006, p. 47).

\section{Mind and body are not two things. A human being is not two ontologically different kinds of thing joined together. Mind is not a mysterious metaphysical guest that just happens to drop in for a temporary visit at the home of the body. The human mind is not contained in the body, but emerges from and co-evolves with the body. (Johnson, 2007, p. 279)}

All dimensions of personhood make all others possible. Take one part away and personhood will be seriously impaired to some degree or another. Your unified nature is what enables and powers the you-ness of you as an extraordinarily complex human being, who experiences everyday life as a seamless flow of conscious and nonconscious experiences of all kinds (thoughts, intuitions, emotions, sensations, memories, etc.).

Another key aspect of personhood is captured in philosopher Evan Thompson's (2007) statement that "self and other enact each other reciprocally through empathy ... human subjectivity is from the outset intersubjectivity, and no mind is an island" (p. 383). In short, personhood is a co-construction between self and others; it's not an isolated, internal thing. It follows that human consciousness is in and of the world, not just "inside your head," and empathy is a cornerstone of human consciousness.

Note that empathy is not the same as sympathy, or pity, or feeling sorry for another person, or agreeing with someone to make them feel good. Empathy means that we adopt (consciously and/or non-consciously) the perspective or affective disposition of another person in an effort to understand that person and respond appropriately to him or her and (depending on circumstances) respond compassionately, responsibly, and ethically. Without empathy, people would be strongly inclined to act selfishly, group cohesion and collaborations would be unlikely (if not impossible) and, at worst, psychopathologies would 
be common. Developmental affective neuroscience (e.g., Decety, 2010) is still a young discipline, but there is increasing evidence that human infants are born with unified bodybrain-mind systems that underpin and propel our ability to develop naturally, informally, and formally the dispositions and abilities to respond empathically to and for the benefit of others. In short, empathy seems to be an innate human propensity. Why else would most parents automatically love and care for their babies, or bond together in families and groups.

We will utilize a musical analogy to summarize several major themes above. The integrated, multidimensional, ever changing processes of personhood, which enable your first-person "I" awareness of your self and your world, are analogous to a huge, multilevel jazz ensemble whose many millions of players (your "personhood processes") are so expert at improvising naturally and collaboratively with your ecological circumstances that the "beautiful music" of you-meaning your unique experience of reality-flows continuously. The players in the ensemble create your experience of you as the arranger and performer of your life's music "in all its complexity, emotional nuance, crescendo and diminuendo - the ballad that is the you-ness of you" (Blakeslee \& Blakeslee, 2007, pp. 207-208).

This analogy helps to summarize the embodied, enactive, empathetic, and ecological concept of personhood and consciousness we have just sketched, which is original to several contemporary cognitive scientist and philosophers of mind (e.g, Noë, 2004, 2009, 2012; Thompson, 2007; Johnson, 2007).

To say that persons are embodied beings is to say that all fundamental processes of personhood, and our other capacities (e.g., emotion, cognition, emotion, memory, etc.) are completely unified. The human brain-mind is in our entire organism and, also, continuously interacting with our multidimensional environments. To say that we are enactive beings emphasizes that each individual actively generates, maintains, brings forth, and actively creates his or her total personhood and personal identities by interacting with other persons and all aspects (social, cultural, political, gendered) of his or her environments.

\section{Well-being, Happiness, and Human Flourishing}

For more than 2500 years, thinkers in the domain of Western philosophy have pondered the natures and values of wellbeing and happiness, which are fundamental dimensions of full personhood. Greek philosophers sought to conceptualize well-being and happiness as processes that were independent of health, wealth, and the ordinary occurrences of daily life. According to the Greeks, "human flourishing" (or eudaimonia) and intellectual happiness were the rewards for a life of virtue.

As part of developing his concept of education, Aristotle studied the governing principles of more than two hundred and fifty different Greek states. (Beginning in 750 BC, Greece experienced 250 years of expansion during which hundreds of individual states and colonies developed in all directions; and the combined population grew from approximately 800,000 to 13 million.) Based on his political investigations and his philosophical principles, Aristotle concluded that the state is the core social entity and that its prime concern should be to educate intelligent, civically engaged, ethical, and happy citizens (Robb, 1943, p. 206). At the core of Aristotle's concept of the good life is his belief that: "Every community shall have as its ultimate goal the attainment of happiness; and that city is best governed which provides the greatest opportunity for its attainment" (Robb, p. 207). However, an important 
distinction must be made between two interlocking meanings of happiness: (a) happiness as a person's subjective experiences of pleasure and positive affect and (b) happiness in the fuller Aristotelian eudaimonic sense of striving to live a productive, meaningful, ethical, and community-oriented way of life that benefits oneself and others.

Aristotle followed Plato in the belief that children should be educated for their productive responsibilities in community life. At the same time, he believed children should engage in guided activities that would develop the "proper virtues" in the processes of learning specific skills and understandings (Noddings, 2012). He insisted that educators and society at large should continually revisit the meaning of human flourishing and the best ways for helping young people achieve eudaimonic ways of life. To him, this meant providing a balanced curriculum for the whole child. Play, debate, music, physical activities, and the study of science and philosophy were necessary for the proper formation of the body, mind, and soul. Aristotle also emphasized the need to balance theoretical and practical reasoning. Like Plato, Aristotle believed that learning should continue throughout life-long study, critically reflective actions, interpersonal relationships, and civic engagement, but with different emphases at different ages (Smith, 2012). The concepts of well-being, happiness, and selffulfilment have been considered and reconsidered from Greek times to the present day. Let us examine some historical aspects of these concepts.

St. Augustine and St. Thomas Aquinas proposed that "loving one's neighbour" is the path to happiness and self-fulfilment. The $19^{\text {th }}$-century poet, cultural critic, and inspector of schools, Matthew Arnold, argued that happiness is both the proof and the reward of righteousness. David Hume held that the pursuit of happiness was the basis of individual motivation and social well-being. Kant construed happiness in terms of moral duty and good will. To John Stuart Mill, happiness includes pleasure and well-being; and in addition, "individuality, freedom, [and] autonomy," all of which have "a constitutive - not just an instrumental relation to it" (Appiah, p. 21).

Nietzsche equated happiness with "a feeling of power" that increases and overcomes resistance. George Santayana (1967) wrote that: "Happiness is the only sanction of life; where happiness fails, existence remains a mad and lamentable experiment" (p. 440). Carl Jung (1962) offered a variation on Santayana's view: "Even a happy life cannot be without a measure of darkness, and the word happy would lose its meaning if it were not balanced by sadness. It is far better to take things as they come along with patience and equanimity" (p. 79). Anne Frank (1967) opined that "Whoever is happy will make others happy, too" (p. 184). Cicero, Bertrand Russell, and Ibsen located happiness in the mind's harmony. Montesquieu, George Hebert, George Bernard Shaw, and Victor Hugo held that genuine happiness was something that involved human sharing or connectedness.

In his book, Better Living: In Pursuit of Happiness from Plato to Prozac, the contemporary Canadian philosopher Mark Kingwell (2000) writes: "Happiness is not about feeling good all the time (p. 307)...getting everything you want is not the source of happiness but of unhappiness, for when striving ceases so does life" (p. 358).

Of course, it is also possible to create a temporary sense of what seems like well-being or happiness. Every culture has created drugs to alter human experiences; for example, marijuana, heroin, and alcohol, and modern treatments for manic-depression such as Lamictal and Depakote. However, as the eminent psychologist Mihalyi Csikszentmihalyi (1999) points out, "chemically induced well-being lacks a vital ingredient of happiness: the 
knowledge that one is responsible for having achieved it. Happiness is not something that happens to people but something that they make happen" (p. 824). Csikszentmihalyi's research on happiness deserves special mention.

After thirty years of research and 18 books, Csikszentmihalyi argues that happiness depends on whether a person is able to derive "flow" from whatever he or she does. "Flow" describes a particular kind of experience that is so absorbing and enjoyable that it is worth doing for the doing itself. The arts and sports are typical sources of flow. Of course, what sets music apart from all other sources of flow is its unique materials and requirements, namely sonic-musical events created and shared by means of socially situated forms of musical understanding and appreciation. One of the most essential ingredients of flow is concentration, and the essential requirement for concentration is a challenge that matches one's abilities. A piece of music is a multidimensional challenge. A person can achieve flow in the processes of performing, improvising, arranging, composing, conducting, and listening to a piece of music if and only if his or her musical skills and understandings match the demands of a piece of music.

We do not mean to suggest that flow is the exclusive domain of elite performers. Not at all. Achieving flow through meeting musical "challenges" (e.g., a piece of music to perform, improvise, compose, arrange) is inclusive of amateur school and community music makers at novice, competent, and proficient levels and, also, professional musicians who have developed expert level of musical abilities. So, in educative, ethical, and praxial music teaching circumstances, a novice can achieve flow in learning to meet the early music making "challenge" of learning and performing Twinkle, Twinkle.

It's worth noting that learning a piece of music that's too far above a person's current level of musical abilities causes frustration; learning a piece that is below a person's ability leads to boredom. In professional contexts, an extraordinary artist can only achieve flow by constantly developing new interpretations of familiar works, seeking out new works, and "pushing" his or her musical abilities to maximum levels.

Viewed broadly, then, achieving life-long flow and happiness in music requires that school and community music makers of all kinds become continuously involved in finding progressively more challenging pieces, interpretations, styles of music, and/or participatory music making contexts (Turino, 2008) that stretch their current levels of abilities (to the extent they desire) and give them constant feedback about how they are progressing in meeting new challenges.

However, if experiences of flow are few and far between during students' musical education, and if students have not had sufficient opportunities to be in control of their own learning, then they will not have the intrinsic motivation and musical independence they need to carry on making and listening to music after they leave school.

Csikszentmihalyi argues that self-esteem and happiness are among the most significant outcomes of musical flow experiences. That is, happiness is usually a consequence of flow, because while we are deeply involved in the processes of meeting an appropriate level of challenge, we do not have time to reflect on our subjective state until of being after a flow experience is over.

Being happy would be a distraction, an interruption of the flow. But afterward, when the experience is over, people report having been in as positive a state as it is possible to feel. Autotelic persons, those who are often in flow, tend also to report more positive states 
overall and to feel that their lives are more purposeful and meaningful. (p. 825)

Moreover, as common sense would suggest, although it is possible to make everyday experiences into flow experiences, complex fields of ethical action like music, which are rich in dynamic and divergent challenges and positive social circumstances allow for and provide support for the continuing emergence of new opportunities for flow development and, therefore, happiness, self-worth, fellowship, and more.

In his book, The Childhood Roots of Adult Happiness, Harvard psychiatrist Edward Hallowell (2002) conceives happiness as an ability that involves five major dimensions, which parents and teachers can help children to develop. These five dimensions are connectedness, play, achievement, practice, and recognition. The most important, says Hallowell, is connectedness, which refers to feeling secure and cared for by others. This is the basis for developing personal optimism, a willingness to take risks, and a "can-do, want-to-do" attitude. Nel Noddings (2003) agrees: "The best schools should resemble the best homes...[They should] provide continuity in caring relations, [and] attend to and continuously evaluate both inferred and expressed needs" (p. 260).

The second dimension is play. Students need opportunities to experiment, problem solve, and act creatively on their own. Hallowell's research argues that experimentation teaches children the ability to tolerate frustration and to fail and try again as they work toward their goals. From a foundation of connectedness, and a disposition to problem solve and keep trying, comes absorption in what one is doing and, next, an appreciation for the importance of practice. Hallowell puts it this way:

\section{A child who plays will soon learn the power of practice. Rare is the child who can ride a bike on the first try without falling off. But such is the allure of being able to ride [or being able to sing or play an instrument well] that practice becomes tolerable... (p. 64)}

Through practice comes achievement and with achievement comes the profound feeling of "I can do this. Now I get it!" The roots of self-esteem lie not in praise, but in achievement and the flow experiences that accompany it: "When a child masters something she couldn't do before-from walking to riding a bike to playing the piano to speaking Spanish-her self-esteem naturally rises, whether she receives any praise or not" (pp. 64-65). If we want our students to develop and sustain happiness, well-being, and self-worth, says Hallowell, we should not go out of our way to praise them; we should make sure that they experience personal achievements in many different ways and in situations of connectedness, security, experimentation, and productive practice. In doing, students will also develop confidence, discipline, initiative, and an enduring desire to work hard.

The fifth dimension is recognition. Achievement leads naturally to recognition by a wider circle of people-parents, extended family, classmates, members of the group (the school band, choir, and so forth), audiences, and so on. A key point here is that "it is important not only that others value and recognize the child but that the child feel valued and recognized for who he or she actually is" (p. 65). Hallowell elaborates this point:

When who the child truly is coincides with what the larger group values, this not only reinforces her desire to do well - to gain approval from others - but it reinforces her own sense that she matters, that she belongs, that she contributes. If you feel recognized and valued by a larger group, you will feel connected to that larger group. When you feel connected to a larger group, you will want to do right by that group, be it your family, 
your team, your class, your neighbourbood, your company... whatever. This feeling of genuine connectedness to a larger group is the root of moral behaviour (pp. 65-66).

\section{Praxial Music Education}

What is praxial music education, and how does the foundation of this philosophy relate to well-being and happiness? We answer these questions in detail elsewhere (Elliott and Silverman, 2014). For now, let us say explain briefly that the concept of praxis originated with Aristotle, many other philosophers-e.g., Martin Heidegger, William James, John Dewey, Hannah Arendt, Shirley Grundy, Joseph Dunne, Richard Bernstein, and Paulo Freire-have contributed to refining the meaning and practical implications of Aristotle's concept during the last 2,400 years.

From our perspective, praxis is a multidimensional concept. Praxis involves active reflection and critically reflective action for the development of (a) personal and community flourishing and wellbeing, (b) the ethical care of others and (c) the positive transformation of people and their everyday lives.

Central to the concept of praxis is careful and caring thinking-and-doing for people's fulfillment and flourishing-musical, cognitive-emotional-bodily, social, cultural, ethical, and educational fulfillment and flourishing.

What does praxis mean for music education? Very briefly, praxial music education conceives musical actions in three related ways:

(a) as critically reflective and informed actions that are

(b) embedded in and creatively responsive to both traditional and everchanging musical/cultural/social values and

(c) understood, taught, guided, and applied ethically and democratically for the positive improvement of students' personal and musical-socialcommunity lives.

When we educate people to make music expressively and listen deeply, we may consider four basic senses of music education: we educate people in music, about music, for music, and through music. Notice the differences (Elliott, 1995; Elliott and Silverman, 2014):

Education in music involves the teaching and learning ${ }^{3}$ of music making and musiclistening.

Education about music involves teaching and learning formal knowledge (or verbal information) about music making, music listening, music history, music theory and so on.

Education for music may be taken in two ways: either teaching and learning as preparation for beginning to do music, or teaching and learning as preparation for a career as a performer, composer, historian, critic, researcher, teacher, or CM

practitioner.

3 Chapters 10, 11, and 12 of Music matters: A philosophy of music education, $2^{\text {nd }}$ ed., makes distinctions among the terms education, schooling, teaching, and learning. 
Education through music overlaps with the first three senses since each can be carried out in direct or indirect relation to such goals as improving people's health, wellbeing, and happiness.

A fifth meaning of "music education" arises by construing "education" as a professional endeavour. A person earns credentials as a music educator and may thereby earn a reputation as well as a living. In this sense, "music education" indicates the professional practice of imparting knowledge in, about, for, or through music, depending on one's beliefs about whether one, or some, or all these senses are important.

So, from a praxial perspective, music making and listening have a very wide range of values (e.g., Elliott and Silverman, 2014, pp. 361-388). Praxial music education and community music have the potential to enable people to develop the abilities and dispositions they require to pursue many of the most important human "life goals" and "life values" for themselves and others: a meaningful life; a life well lived; a life of personal and community well-being (cognitive, emotional, cultural, etc.); personal fulfillment; a life of felt significance; and happiness for oneself and others - in short, a life of fuller human flourishing.

Summing up, praxial music education argues that music educators should be guided by a musically and educationally informed, ethical, and caring disposition. Music educators should act and teach artistically, creatively, democratically, and educatively, with a continuous concern for improving people's well-being in as many ways as possible including (but not limited to) people's personal, musical, emotional, cognitive, bodily, social, cultural, creative, political, ethical, and democratic well-being.

\section{Implications for Music Education}

Music is "good for" many things. Because of the positive musical-emotional experiences music listening and music making can arouse and express, music-taught educatively-can make major artistic, social, cultural, ethical, economic, and political differences in peoples' lives. Music does not have one value; music has many values. For example, when music education is ethically guided-when we teach people not only in and about music but also through music, we have greater opportunities to strive for and achieve many dimensions of eudaimonia, which are the ultimate aim of praxis and a central aim of our praxial philosophy of music education.

Is it possible to witness well-being or happiness in others? Yes. In fact, we are constantly engaged in assessing people's publically expressed emotional states. Doing so is a necessary part of getting around in our social worlds and communicating with others. We can and do notice when people are angry, sad, cheerful, frustrated, and so forth, especially when we know people well. But let us add more weight to this claim.

Antonio Damasio and Joseph LeDoux, two of today's most respected neuroscientists and emotion researchers, make a crucial distinction between emotions and feelings. Based on decades of research, they both argue that emotions are unconscious processes that arise from our perception of endless details of our situations such as threats, temptations, personal inclinations and attachments, cultural artefacts, and so forth. Feelings occur when we become consciously aware of changes in our unconscious emotional states (LeDoux, 2002, p. 225).

Two things follow from the research of Damasio (2003), LeDoux (1996, 2002), and many 
other scholars. First, emotions precede feelings. Second, emotions display themselves outwardly. We notice changes in people's facial expressions, movements, posture, and voices that communicate their emotions. Noticing these changes is absolutely crucial to understanding each other, including our school students and community music participants. If someone looks or sounds frightened, angry, or joyful, we assume from these outward physical changes that he or she is feeling fear, anger, or joy and, if necessary, we can change our actions and dispositions.

Of course, it is never possible to experience what another person is actually feeling. Unlike emotions, feelings are always private and internal. So you might ask, are our judgments of other's emotions and feelings reliable? Yes, in many cases, most of us are good judges of the emotions of others, especially people we know ell. Also, considerable research (e.g., Juslin et al., 2011; Huron, 2006) supports suggests that music listeners' can hear and, in any cases, feel the emotions they believe particular pieces and performers express or communicate. We suggest, therefore, that in a music classroom, and elsewhere, we can observe indications of music makers' emotions of enjoyment, flow, and happiness (or the opposite) as they make music and as they communicate with each other and their teachers nonverbally and verbally.

Bringing this discussion to a close, we propose that several interrelated and co-dependent ingredients are both descriptive and predictive of happiness: a sense of connectedness, security, and personal autonomy; a disposition to play, experiment, strive, and practice toward increasing levels of achievement and repeated flow experiences; a desire to do things for their own sake; and a feeling of being recognized and valued for oneself and one's contribution to a group.

It seems fair to suggest that many music classrooms, community music settings, and private studios have been and continue to be-or have the potential to be-situations and sites of musical and intersubjective interaction where students can experience happiness, flow, fellowship, care for others, well-being, and many other attributes of eudaimonia. This is so because many school and community musicians deliberately and/or intuitively teach toward these ends and know how to create educational conditions that will make it more likely that people will attain some of these musical-personal values, or human "goods."

The challenge, then, is to make musicians of all kinds, including music educators, more aware of all the values that eudaimonia involves and that are available and achievable through educative and ethical music teaching and learning. In so doing, we will be more likely to improve students' musical abilities and enjoyment of music making because the foundations of optimal musical accomplishment and the values of eudaimonia are, in fact, the same: namely, confidence, self-esteem, accumulating pride and happiness in and through one's accomplishments, resilience and flexibility in dealing with temporary frustration and failure, a disposition to search for creative solutions to musical problems, an appreciation for the values of sustained practice, and a personal desire to contribute musically and socially to the positive transformation of oneself, others, and one's community at large.

\section{References}

Appiah, K.A. (2005). The ethics of identity. Princeton: Princeton University Press. 
Barz, G. (2006). Singing for life: HIV/AIDS and music in Uganda. New York: Routledge.

Barz, G. (2008). The performance of HIV/AIDS in Uganda: Medical ethnomusicology and cultural memory. In B. D. Koen, J. Lloyd, G. Barz, and K. Brummel-Smith (Eds.), The Oxford handbook of medical ethnomusicology, pp. 164-184. Oxford: Oxford University Press.

Beck, C. (1974). Educational philosophy and theory. Boston: Little Brown.

Bernstein, N. (2001, 8 April). One family's wandering comes to an end. The New York Times. Retrieved 11 November 2008, from http://www.nytimes.com

Blakeslee, S. \& Blakeslee, M. (2007). The body has a mind of its own: How body maps in your brain belp you do (almost) everything better. New York: Random House.

Burns, G. (1984). Dr. Burns' prescription for happiness. New York: Putnam’s Sons.

Connect America (1997). What works: Art Start sparks creativity in NYC shelters. Connect America, 1(2). Retrieved 23 February 2008, from http://www.artstart.org/pdfs/connectamerica.pdf.

Csikszentmihalyi, M. (1999). If we are so rich, why aren't we happy? American Psychologist, 54(10), 821-827.

Damasio, A. (2003). Looking for Spinoza: Joy, sorrow, and the feeling brain. Orlando, FL: Harcourt.

Decety, J. (2010). The neurodevelopment of empathy in humans. Developmental Neuroscience, 32(4), 257-267.

Frank, A. (1967). The diary of a young girl. New York: Doubleday.

Elliott, D., \& Silverman, M. (2014). Music matters: A philosophy of music education, $2^{\text {nd }}$ ed. New York: Oxford University Press.

Hallowell, E. M. (2002). The childhood roots of adult happiness. New York: Ballantine Books.

Huron, D. (2006). Sweet anticipation: Music and the psychology of expectation. Cambridge MA: MIT Press.

Johnson, M. (2006). Mind incarnate: From Dewey to Damasio. Daedalus, 135(3), 46-54.

Johnson, M. (2007). The meaning of the body: Aesthetics of human understanding. Chicago: The University of Chicago Press.

Jung, C. G. (1962). Memories, dreams, reflections. London: Collins York: Vintage.

Juslin, P. N., Liljeström, S., Laukka, P., Västfjäll, D., \& Lundqvist, L. (2011). Emotional reactions to music in a nationally representative sample of Swedish Adults: Prevalence and causal influences. Musicae Scientiae, 15(2), 174-207.

Kingwell, M. (2000). In pursuit of happiness: Better living from Plato of prozac. New York: Crown.

LeDoux, J. (1996). The emotional brain. New York: Simon \& Schuster.

LeDoux, J. (2002). The synaptic self. New York: Viking Press.

Muller, C. (2008). Singing for life: HIV/AIDS and music in Uganda by Gregory Barz: A 
review. The World of Music 50(1), 112-114.

Noddings, N. (2003). Happiness and education. New York: Cambridge University Press.

Noddings, N. (2012). Philosophy of education, $2^{\text {nd }}$ ed. New York: Westview Press.

Noë, A. (2004). Action in perception. Cambridge, MA: MIT press.

. (2009). Out of our heads: Why you are not your brain, and other lessons from the biology of consciousness. New York: Hill and Wang.

. (2012). Varieties of presence. Cambridge, MA: Harvard University Press.

Noguera, P. (2009). Education in changing contexts. Lecture conducted at Ross Institute Summer Academy, Retrieved from: http://goo.g1/4CrMeY

Phelan, H. (2008). Practice, ritual and community music: Doing as identity. International Journal of Community Music, 1(2), 143-158.

Phelan, H. (2012). Sonic hospitality: Migration, community, and music. In G. McPherson \& G. Welch (Eds.), The Oxford handbook of music education, Vol. 2, pp. 168- 184. New York: Oxford University Press.

Robb, F. C. (1943). Aristotle and education. Peabody Journal of Education, 20(4), 202- 213.

Rolle, C. (2007, 24 July). Testimony of Chris “Kazi” Rolle Creator of Art Start's Hip-Hop Project Before the US House of Representatives Committee on Education and Labor Subcommittee on Healthy Families and Communities. Retrieved 16 November 2008, from http://goo.gl/5e1gW0

Santayana, G. (1967). Animal faith and spiritual life. New York: Appleton-Century-Crofts.

Smith, M. (2012). Aristotle, The Encyclopedia of Informal Education, Retrieved at http://www.infed.org/thinkers/et-arist.htm. Accessed January 10, 2013

Talcott, C. (2007, 11 May). For young hip-hop artists, a head start in music and life. Washington Post, p. WE44. Retrieved 8 March 2008, from http://goo.gl/PCc8a4

Thompson, E. (2007). Mind in life. Cambridge, MA: Harvard University Press.

Turino, T. (2008). Music and social life: The politics of participation. Chicago: University of Chicago Press.

Williams, K. (2007, 10 May). Kazi's hip-hop project. Black Star News. Retrieved 7 March 2008, from http://blackstarnews.com/?c=135\&a=3297 